\title{
MANETTO DI JACOPO AMANNATINI, THE FAT WOODGARVER
}

\author{
ARCHITEGTURE AND MIGRATION \\ IN EARLY RENAISSANCE FLORENCE**
}

\begin{abstract}
The Story of the Fat Woodcarver, written by Antonio di Tuccio Manetti, probably recalls a popular anecdote about a Florentine artisan who was humiliated by his friend, Filippo di ser Brunellesco. The joke played by the architect has been at the forefront of scholarly interest, while the main protagonist has so far received limited attention. This article aims to reconstruct the life of Manetto di Jacopo Amannatini, that is, the Fat Woodcarver, in the context of his social relationships with the other figures in the story. It argues that Manetti's account is grounded in concrete historical facts and therefore provides us with a unique picture of the intersections that existed between artisan and merchant networks in and beyond early Renaissance Florence. Manetto's character may well symbolize those itinerant craftsmen who, by acknowledging their position in their own communities, and thanks to their skills and their courage to migrate to remote places, like the Kingdom of Hungary, managed to improve their social status significantly.
\end{abstract}

Keywords: Il Grasso legnaiuolo, the Fat Woodcarver, Manetto Amannatini, Antonio di Tuccio Manetti, Pippo Scolari, Lo Spano, Filippo Brunelleschi, Donatello, Florence, Hungary, architecture, Renaissance

The circulation of Florentine artisans within and beyond the Italian Peninsula took a regular form with the spread of the Florentine Renaissance, which conquered new territories partly due to artisan migration. The correlation between the two phenomena was still in its infancy at the beginning of the fifteenth century, however, at a time when the eventual leading masters of the new taste, Filippo di ser Brunellesco, Donato di Niccolò Bardi (Donatello), Lorenzo di Bartolo Ghiberti and Tommaso di Cristofano (Masolino), had just started their careers. The earliest narrative source about a Florentine artisan working beyond the Alps is considered to be $L a$ Novella del Grasso legnaiuolo (The Story of the Fat Woodcarver), composed by the Florentine

\footnotetext{
* Katalin Prajda is a postdoctoral research scholar at the Department of Medieval Studies, Institute of History, Research Centre for the Humanities, Hungarian Academy of Sciences, Budapest; e-mail: katalin.prajda@eui.eu

$* *$ For his constructive criticism on earlier drafts of this article I would like to thank Lorenz Böninger. I am indebted as well to Amy Samuelson for revising the text.
}

humanist, Antonio di Tuccio Manetti (14231497). Its protagonist, Manetto di Jacopo Amannatini, or the Fat Woodcarver, who became an architect in the Kingdom of Hungary, is known to us almost exclusively through Manetti's story.

As Lauro Martines points out, La Novella is a remarkable account not only of a woodcarver's life events but also of the intersections between the elite and artisan networks of early Renaissance Florence. ${ }^{1}$ Though some scholars claim that Filippo di ser Brunellesco - one of the protagonists - and Manetti would have known each other, aside from Martines's analysis, most studies have only touched upon the question of whether or not the story actually happened. ${ }^{2}$ According to Mary Bergstein "...the persona of the woodcarver was almost surely invented, for no successful Florentine artisan could have been quite as ingenuous or unstable as the credulous Grasso." 3 Bergstein is probably right in saying that the credulous and unstable side of the Fat Woodcarver's character might have been invented. However, as we shall see, the story 
itself and its protagonist had more to do with reality than scholars have previously assumed. The present article aims to shed a critical light on the details provided by La Novella regarding the Grasso legnaiuolo's life, confronting them with emerging written sources housed by the Florentine National Archives.

The three versions of La Novella del Grasso legnaiuolo, transmitting what was probably a popular story, have survived in numerous manuscripts ranging between the first three decades of the fifteenth century and the $1480 \mathrm{~s} .{ }^{4}$ The third variant, likely composed by Antonio Manetti, supplements La Vita di Filippo Brunelleschi. Margaret Haines maintains that the information provided by Manetti is reliable on many points regarding Filippo's life. ${ }^{6}$ It is interesting to note, however, that besides a letter written by Antonio di Tuccio Manetti (1423-1497) in which he mentions Filippo di ser Brunellesco (1377-1446), scholars have not succeeded so far to establish a personal connection between Manetti and any of the protagonists of La Novella. ${ }^{7}$ Given the considerable age difference, it is very problematic to reveal any social ties between them or between their families. ${ }^{8}$ Nonetheless, as we shall see later, it is still plausible that the humanist knew some of the Grasso's relatives in Florence.

The main protagonist of La Novella was identified by Domenico Maria Manni in 1744 as the Florentine woodcarver, Manetto di Jacopo Amannatini. ${ }^{9}$ Since then, scholarly works, when testing the reliability of the story, have relied exclusively on a tax declaration submitted by the Amannatini brothers in 1442, the only archival source published about him thus far. ${ }^{10}$ Though Gaetano Milanesi refers in his study to other written documents, such as Manetto's investments into the public debt, the Monte Comune and his later catasti, he fails to mention their location. ${ }^{11}$ The Florentine National Archives, however, houses several other contemporary manuscripts, such as the family's tax returns in 1427 , 1433, 1446, 1452, 1458 and several entries in the Monte Comune and the Monte delle doti, the Florentine dowry fund as well as his testament, which have proved to be valuable in the reconstruction of Manetto Amannatini's life. Besides these, a draft of a letter has come to light which so far is the only explicit archival evidence proving that Manetto worked for the Florentine-born baron Pippo Scolari. All these sources seem to underline several key points of La Novella.

According to Manetti, the story encapsulated in the anecdote dates back to 1409 , when Filippo di ser Brunellesco, a good friend of Manetto, returned from Rome. ${ }^{12}$ At that time, Manetto Amannatini was running a workshop in the Piazza di San Giovanni and besides maintaining friendship with other artisans of the city, among them the already mentioned Filippo, he was acquainted also with a few members of the political elite. He had already acquired name in the city with his craft and became famous also for his credulousness. One evening, while having had dinner at the house of a respected citizen, Tomaso Pecori, Filippo, as one member of the company, had the idea to teach Manetto a lesson. The cruel joke starts with the false alarm of the near death of Manetto's mother, who urgently left the dinner table at Tommaso Pecori for checking whether his mother had arrived home from the countryside. At the same time, members of his dinner company rushed also to his house, locked him out and played a kind of voice theater making him believe that his mother indeed was already back and that he was conversing with her inside the house. Having been almost completely confused by the performance while standing outside of his own home, Manetto met another member of his dinner company, Donatello, who greeted him as "Matteo" and not "Manetto" and confirmed that the one inside the house was the Grasso himself. He had very limited time to think over the whole story when six guardsmen and an officer of the merchants' court arrived there and arrested him for business debt as Matteo Mannini. In consequence, he spent a night in prison and when the next morning another member of the dinner group, Giovanni Rucellai saw him in his cell, he also pretended not to recognize him. After Rucellai's visit, there came two men who pretended to be the Grasso's brothers and bailed him out of prison. After having been dismissed from prison, the two pretend-to-be-brothers of Matteo took him into their own home, located in the other side of the river, in the parish of Santa Felicita. They asked the parish priest, who knew only slightly the brothers, to have a few words with Manetto in order to convince him fully that he was in fact Matteo Mannini. The woodcarver, after the priest' visit, and an abundant dinner 
spent with his fake-brothers, fell asleep. While asleep, his companions carried him way back to his own house, put him into his own bed and arranged everything around him if nothing had happened since the dinner at Tomaso Pecori's house. By waking up next morning, Manetto felt uncertain again whether he had been dreaming the whole story of Matteo Mannini or he was dreaming now of turning back into the woodcarver Grasso. Led by the curiosity of trying to figure out who he exactly was, he met in the square his friends, Filippo di ser Brunellesco and Donatello. They were talking about the arrest of Matteo Mannini, who claimed to be the Grasso, pretending that they knew nothing about the story. While revealing details of the event as a gossip circulating throughout Florence, the true Matteo arrived to the scene and assured them that he had been away in the countryside and was no way taken into prison in the other night. Following this conversation and an urgent visit at his mother in the countryside, the Grasso concluded that he had become, indeed, the victim of a cruel joke played by his friends. Ashamed by his credulousness, Manetto decided to leave Florence for the Kingdom of Hungary at the invitation of one of his fellow-artisans working in Pippo Scolari's service. The Grasso, taking up the opportunity offered by the baron, acquired social status and a good reputation as an architect in his adopted country. Whenever he returned to his native Florence for short visits, he did not forget to contact his old friend Filippo, as both were now successful architects. This is the version of the story told by Antonio Manetti's La Novella.

Studies until now have concentrated on the joke itself, paying little attention to its protagonist or to one of the key elements of the story, migration, which later became a widespread practice among Florentine artisans. The phenomenon was not entirely new at the beginning of the fifteenth century. By this time a good number of artisans had migrated to other Tuscan destinations as well as to Rome and the Venetian Republic to undertake commissions. Brunelleschi had already spent some time in Rome, and Lorenzo Ghiberti in Pesaro. Only sporadic evidences suggest that they ventured beyond the Alps, however, and all returned home after a couple of months abroad. ${ }^{13}$

Manetto Amannatini's reason for leaving his native Florence for the Kingdom of Hungary might have had something to do with Lauro Martines's claim that the woodcarver was by no means a fool. According to La Novella, the credulous Manetto was famous for his skills in making altarpieces and panel-painting pediments, and he already kept an independent workshop in the city center. ${ }^{14}$ However, he might have been rather competitive in nature, not content with small achievements, and he probably did not want to live in the shadow of the talented Filippo di ser Brunellesco. Filippo was almost a decade older than Manetto and already a respected artisan. The age difference between them and Filippo's ability in design and construction left little room for Manetto or other masters to shine. No evidence at our disposal suggests that Manetto was aspiring to become an architect as early as his departure for the Kingdom of Hungary, though there were other woodcarvers his age who did in fact try to test their abilities as architects and/ or engineers. Sometimes wooden models prepared for building projects marked the first steps toward such a career. ${ }^{15}$ Manetto's workshop was located just next door to the construction site of the cathedral where Filippo had been serving as advisor since 1404. Another skilled woodcarver, Antonio di Manetto Ciaccheri (Manetti), prepared wooden models for Brunelleschi; later, in 1436, he became Filippo's rival in a competition for the construction of the lantern of the Santa Maria del Fiore. ${ }^{16}$

By the early fifteenth century, a small segment of the Florentine society had accumulated significant wealth, which became one of the main drivers toward pursuing voluminous building projects. ${ }^{17}$ This phenomenon of course had a direct impact on the size of the labor force employed in construction work, and it also contributed to the stability of workers' economic and social conditions. It is no wonder, then, that the relative number of woodworkers living in the city increased compared to previous decades. (Fig. 1)

Maria Letizia Grossi, by studying the 1427 catasto, found that 51 legnaiuoli workshops were functioning in the city at the time when Manetto and his friends were at the peak of their careers. ${ }^{18}$ Six years later, in the 1433 catasto, 13 bottega di legnaiuolo were reported by one of the masters or partners, which means that some of the companies ran more than one workshop in the city. ${ }^{19}$ In the same catasto, we find 61 legnaiuoli house- 


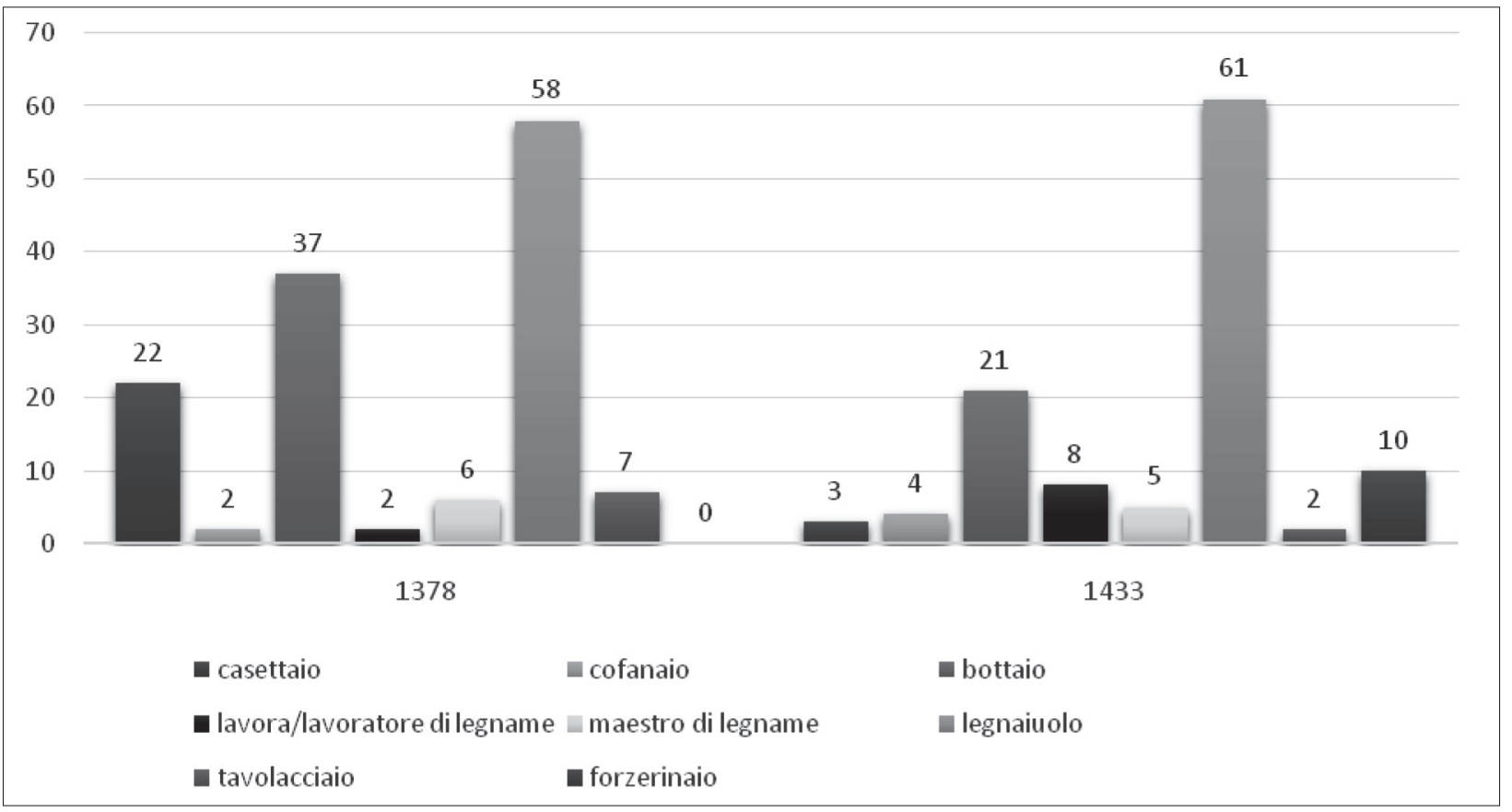

Fig. 1. Number of various woodworkers' households in the 1378 and in the 1433 city censuses.

The statistical data is based on the Prestanze 1378 and on the Catasto 1433. ASF Prestanze 366-369,

Catasto 487-500 (campioni), Catasto 454-455 (portate since the corresponding campioni are missing)

holds from a total of 7898 declarations. Among them, seven legnaiuoli had established family names. ${ }^{20}$ (Fig. 2) This shows that they did not come from the highest strata of the society, where family names were more widespread, nor did they belong to the lowest strata, since the majority owned enough mobile and immobile properties in the city to support an entire household. Only four among them did not have taxable assets. More than fifty years earlier, in 1378 - approximately the time of Manetto's birth - the Florentine census, the Prestanze, mentions 58 legnaiuoli households in the city for a total of 12,414. These statistical evidences, therefore, suggest that their relative as well as their absolute number increased significantly between the beginning and end of the Albizzi regime. ${ }^{21}$ Thus, a comparison of the two statistical data sources seems to indeed confirm Richard Goldthwaite's claim that the construction sector experienced considerable growth during the first decades of the fifteenth century, requiring an expanded workforce.

Legnaiuoli were most commonly enrolled in either the Arte dei Legnaiuoli or the Arte di Maestri di Pietra e Legname, though guild membership was not a prerequisite in Renaissance Florence for practicing one's profession. Sources are very few in number regarding the abovemen- tioned guilds; only some of the matriculations have survived. It is therefore not surprising that there are no references to Manetto. ${ }^{22}$ Maybe he was in Hungary, or maybe the corresponding books have subsequently been lost.

The Kingdom of Hungary during the reign of Sigismund of Luxemburg also saw extensive building projects. Castles and churches were erected, restored and decorated at this time, and these projects very often involved non-indigenous artisans. Buda, the seat of King Sigismund, provided a new home for several Florentine merchants who traveled to Hungary for business purposes. ${ }^{23}$ By the first decade of the fifteenth century, news about Pippo Scolari, who had been raised to baronial rank by the Hungarian king, had also reached Florence. The Florentine government had even congratulated him on his achievements and asked him to help other Florentines in the Kingdom. ${ }^{24}$ Lo Spano, as his contemporaries called him, was in fact eager to do business with and commission projects for other Florentines, and he built up a network of his fellow-citizens who worked for him in Hungary. ${ }^{25}$ He also took the lead among the noblemen of the Kingdom in investing in building projects of various sorts, including castles, defense systems, churches and chapels. He was therefore in need 
of a reliable, well-skilled workforce. As Masolino's sojourn in Hungary exemplifies, he gave preference in this regard to Florentines. ${ }^{26}$

According to Antonio Manetti, the story of La Novella occurred in the winter of 1409, after which Manetto departed from Florence to meet his fellowartisan in Bologna, with whom he continued his journey to the Kingdom of Hungary. ${ }^{27}$ It might be accidental that Pippo Scolari travelled back to his native Florence in June 1410, though this is highly unlikely. This was the only visit he made in an official capacity to the city, having also spent several days in Bologna where he had audience with Pope John XXIII. ${ }^{28}$ It is plausible that the artisan came back with his master, Pippo Scolari, and was recruiting workers in Florence and Bologna to join them on their way back to the Kingdom of Hungary. ${ }^{29}$ While in search of adventurous artisans, the Spano spent several weeks paying official visits in both Florence and Bologna. By comparing the information, provided by La Novella with Pippo's life events, we can reasonably argue that the story most likely happened before the beginning of the Florentine New Year, March 25, 1410. Consequently, the Grasso might have followed Pippo Scolari to the Kingdom of Hungary in August 1410, several months after the cruel joke. ${ }^{30}$ In the meantime, he had the possibility to sell his workshop as well as to close any unfinished business he might have had in Florence.

La Novella also mentions that Manetto was at that time 28 years old, which would place his birth in 1382. ${ }^{31}$ Contradicting Manetti's data, the tax declarations suggest that he was born sometime between 1385 and 1387, and was therefore one of the youngest members of the company, approximately the same age as Donatello (13861466), but younger than Brunelleschi (13771446). ${ }^{32}$ His nickname, Il Grasso, most probably refers to a personality trait, and is not in my opinion a sign, as Martines claims, of lower social status and a diminished standing compared to the rest of the company. ${ }^{33}$ In fact, this appellative was quite common in contemporary Florence, and we find several men of various social statuses holding this name, including unskilled workers as well as Florentine politicians. ${ }^{34}$ The city experienced a boom of surnames during this period as many popolani families attempted to establish lineages. Manetto's family had already developed a family name, which came from the name of his grandfather, Amannato, though this remains uncovered in the story. Manetto's family was identified only in the eighteenth century by Manni, though he was misled by information on the Tecchini family. ${ }^{35}$ Therefore, Gaetano Milanesi was the first to make an attempt to reconstruct the genealogy of the Amannatini family, though he did not cite any archival sources beyond the 1442 diecina graziosa. ${ }^{36}$ (Fig. 3)

The story refers to Manetto's mother as mona Giovanna, instead of Nera as she was called in original documents. His father, Jacopo, and his uncles, Niccolò, Michele and Manetto, were registered by 1378 as inhabitants of the San Giovanni parish. ${ }^{37}$ According to La Novella, Manetto's workshop, probably part of his paternal inheritance, was also located in the Piazza di San Giovanni. $^{38}$ The Grasso's grandfather, Amannato, and his uncles, Manetto and Michele, were painters and members of the Doctors' Guild. ${ }^{39}$ By contrast, his father worked as a cofanaio, a maker of boxes and caskets. ${ }^{40}$ Other members of the Amannatini family, including Manetto's other uncles and cousins, were either makers of rope or merchants of the $\mathrm{W}_{\text {ool Guild. }}{ }^{41}$ They also occupied some public offices in the late forteenth century. ${ }^{42}$ We can thus agree with Martines that Manetto might have had one of the most humble origins of the group, but he definitely had a more prestigious background than most of the artisans of the period, including Donatello. ${ }^{43}$

The financial situation of his family was likely exacerbated significantly by his father's early death, occurring sometime before 1405 . Thereafter the young Manetto became the sole supporter of his mother and his younger brother. ${ }^{44}$ At that time, Manetto was about twenty years old or even younger, and his brother Niccolò was still a teen. Niccolò had no salary in the years when their taxes were declared. ${ }^{45}$ In 1433, their mother did not fail to mention that her youngest was "non è in suo sentimento," probably referring to his incapacity to support himself. ${ }^{46}$ In the 1442 declaration, Niccolò admits that earlier he worked as a funaiolo, making ropes with his cousin. ${ }^{47}$ In fact, in 1427 and 1433, Giovanni di Manetto Amannatini ran a bottega di funaiolo in which Niccolò might have been employed for a short period of time. ${ }^{48}$ Later, though, Niccolò continued to live in the family house with his wife and 


\begin{tabular}{|c|c|c|c|c|}
\hline Name & $\begin{array}{l}\text { Total assets } \\
\text { Florin, soldi }\end{array}$ & $\begin{array}{l}\text { Taxable assets } \\
\text { Florin, soldi }\end{array}$ & $\begin{array}{c}\text { Tax } \\
\text { Composto* } \\
\text { Florin/soldi/denari } \\
\end{array}$ & Location** \\
\hline Giovanni d'Attaviano & Non data & 0 & s.4 & 11 \\
\hline Bernardo d'Andrea di Lottino & f. 464 s. 14 & 0 & s.3 & 12 \\
\hline Giovanni di Mariano & f. 135 s. 16 & 0 & s.3 & 12 \\
\hline Marco di Mariano & f. 130 s. 14 & 0 & s.3 & 12 \\
\hline Antonio di Giovani & f. 57 s. 6 & 0 & s.3 & 13 \\
\hline Giuliano di Cristofano & f. 589 s. 14 & 0 & s.6 & 13 \\
\hline Lorenzo di Domenico & f. 217 s. 7 & 0 & s.3 & 13 \\
\hline Niccolò di Guido & f. 102 & 0 & $\mathrm{~s} .2$ & 13 \\
\hline Domenico di Neri & f. 275 s. 2 & 0 & s.3 & 14 \\
\hline Guernieri di Lorenzo & f. 106 s. 9 & 0 & No data & 14 \\
\hline Jacopo di Giovanni & f. 221 s. 18 & 0 & s.3 & 14 \\
\hline Lorenzo di Salvestro & f. 107 s. 16 & 0 & s.3 & 14 \\
\hline Mariotto di Giovanni & f. 121 s. 17 & 0 & No data & 14 \\
\hline Nanni di Spinello & f. 5 & 0 & No data & 14 \\
\hline Lapaccio di Simone & f. 420 s. 16 & 0 & $\mathrm{~s} .5$ & 21 \\
\hline Salvi di Giovanni & f. 179 s. 19 & 0 & Miserabile & 21 \\
\hline Jacopo d'Andrea Gianni*** & f. 1384 s. 13 & f.133.s.17 & Catasto f.1.d.7 & 22 \\
\hline Lionardo di Cristofano & f. 117 s. 18 & 0 & s.3 & 22 \\
\hline Antonio di ser Francesco & f. 288 & 0 & No data & 23 \\
\hline Cristofano di Piero & f. 590 s. 15 & 0 & s.10 & 23 \\
\hline Giuliano di Poggino & f. 71 s. 20 & 0 & No data & 23 \\
\hline Miniato di Mainardo & f. 186 s. 12 & 0 & Miserabile & 23 \\
\hline Bernardo di Tommaso & f. 299 s. 10 & 0 & s. 2 & 24 \\
\hline Francesco di Giovanni di Guccio & f. 42 & 0 & s.2 & 24 \\
\hline Nardo di Spinello & f. $131 \mathrm{~s} .12$ & 0 & s.3 & 24 \\
\hline Bartolomeo di Tommaso Finiguerra & f. 58 s.18 & 0 & s.2 & 32 \\
\hline Bernardo di Michele & f. $53 \mathrm{~s} .18$ & 0 & $\mathrm{~s} .2$ & 32 \\
\hline Guasparre di Bartolomeo & f. 214 s. 7 & 0 & s.3 & 32 \\
\hline Lorenzo di Niccolò & f. $660 \mathrm{~s} .11$ & 0 & s.10 & 32 \\
\hline Piero di Marco di Giovanni & f. 227 s. 6 & f.27.s.6 & Catasto s.2.d.8 & 32 \\
\hline Corbino di Bartolomeo & f. 874 s.1 & 0 & s.6 & 33 \\
\hline Domenico di Giovanni & f. 279 s. 12 & 0 & No data & 33 \\
\hline Filippo di Giovanni di Piero Canacci & f. 644 s.5 & 0 & s.4 & 33 \\
\hline Giovanni di Francesco di Batino & f. 333 s.11 & 0 & s.4 & 33 \\
\hline Giovanni di Chirico & f. 25 & 0 & Miserabile & 34 \\
\hline Lorenzo di Niccolò del Corona & f. 291 s. 19 & 0 & No data & 34 \\
\hline Manno di Benincasa Manucci & f. 140 & 0 & $\mathrm{s.5}$ & 34 \\
\hline Bartolomeo di Benincasa & f. $255 \mathrm{~s} .2$ & 0 & s.6 & 41 \\
\hline Dino di Francesco & f. $150 \mathrm{s.} 17$ & 0 & No data & 41 \\
\hline Domenico di Domenico di Pagno & f. $138 \mathrm{s.17}$ & 0 & s.3 & 41 \\
\hline Francesco d'Antonio & f. 154 s.8 & 0 & s.3 & 41 \\
\hline Simone di Bruno & f. 10 & 0 & No data & 41 \\
\hline
\end{tabular}

Fig. 2. Active woodcarvers' (legnaiuolo) households in the 1433 Catasto

* The majority of woodcarvers did not possess any taxable assets, therefore they paid instead of catasto, composto. Miserabili were those persons who had less taxable assets than 200 Florins per capita.

** Quarter of S. Spirito: 11=Scala, 12=Nicchio, 13=Ferza, 14=Drago; Quarter of S. Croce: 21=Carro, 22=Bue, 23=Leon Nero, 24=Ruote; Quarter of S. Maria Novella: 31=Vipera, 32=Unicorno, 33=Leon Rosso, 34=Leon Bianco; Quarter of S. Giovanni: 41=Leon D'Oro, 42=Drago, 43=Chiavi, 44=Vaio.

*** In the case of Jacopo d'Andrea Gianni, called Barbetta, the extraordinary high taxable assets are probably due to his participation in the construction works of the Cathedral of the Santa Maria del Fiore, between 1421 and 1436.

Archivio dell'Opera di Santa Maria del Fiore. II. 179. 71r-72r. (1421), II. 413. 84v. (1434), 89v (1435), 92v (1435), 135v (1435), 104v (1436). For the workforce employed in the costruction of the Cathedral see: Pierluigi TERENZI,

"Maestre e organizzazione del lavoro negli Anni della Cupola," Gli Anni della Cupola. Studi, 1 (2015) [accessed on 1 July, 2016, ISSN: 2364-6373] 


\begin{tabular}{|l|l|l|l|c|}
\hline Name & \multicolumn{1}{|c|}{$\begin{array}{c}\text { Total assets } \\
\text { Florin, soldi }\end{array}$} & $\begin{array}{c}\text { Taxable assets } \\
\text { Florin, soldi }\end{array}$ & $\begin{array}{c}\text { Tax } \\
\text { Composto* } \\
\text { Florin/soldi/denari }\end{array}$ & Location*** \\
\hline Taddeo di Manetto da Colle & No data & 0 & No data & 41 \\
\hline Antonio Mannetti & f. 157 s. & 0 & No data & 42 \\
\hline Andrea di Cipriano & f. 167 s.6 & 0 & No data & 42 \\
\hline Barolo di Giovanni Bindi & f. 583 s. 12 & 0 & s.7 & No data \\
\hline Bartolo di Giovanni & No data & 0 & s.3 & 42 \\
\hline Guasparre di Marchese & f. 129 s. 12 & 0 & s.3 & 42 \\
\hline Giovanni di Betto di Francesco & f. 275 s. & 0 & s.5 & 42 \\
\hline Donato d'Andrea & f. 571 s. 1 & s.3 & 43 \\
\hline Giovanni di Nardo & f. 142 s. 4 & 0 & No data & 43 \\
\hline Maso di Domenico & f. 77 s. 10 & 0 & s.4 & 43 \\
\hline Nardo d'Andrea Bocchi & f. 622 s. 6 & 0 & s.3 & 43 \\
\hline Donato di Bartolomeo & f. 194. s. 4 & 0 & s.3 & 44 \\
\hline Domenico d'Antonio & f. 76 s. 3 & 0 & Miserabile & 44 \\
\hline Francesco di Filippo di Goro & f. 66 & 0 & s.3 & 44 \\
\hline Giovanni di Lorenzo & f. 123 & 0 & s.3 & 44 \\
\hline Mariano di Giovanni & f. 174 s. 17 & 0 & s.2 & 44 \\
\hline Maso di Domenico & f. 137 s. 16 & 0 & s.3 & 44 \\
\hline Simone d'Antonio & f. 269 s. 1 & 0 & s.3 & 44 \\
\hline Ventura di Tuccio & f. 163 s. 17 & 0 & 44 \\
\hline
\end{tabular}

Fig. 2. continued

children, apparently relying in financial matters on his brother's help. ${ }^{49}$ If any real person at all inspired Manetti's figure of the credulous and simple-minded woodcarver, then the Grasso's brother might have provided him with an example. The buon "Lausso," as he was nicknamed, had no salary and lived in his mother's household as an adult; therefore, he could have been the perfect prototype of a socially and financially handicapped figure.

Besides Manetto's mother, other Florentines appear in the story, including Manetto's friends: Giovanni di Bernardo Rucellai, Tommaso di Jacobo Pecori, Donatello di Niccolò Bardi and Filippo di ser Brunellesco, as well as two other woodcarvers, including his former master, called Pellegrino delle Tarsie. The joke played by Brunelleschi on Manetto also included the frequent mention of a certain Manetto Mannini, who was falsely identified as the woodcarver by his fellows. We do not know if they were acquainted with each other at all. However, archival sources confirm that they were certainly contemporaries. Giovanni Rucellai and Tommaso Pecori were supposedly older than the three artisans and the rest of the company; both had already passed away by the time of the first general census. ${ }^{50}$ Tommaso di Jacobo Pecori might have been a respected citizen who also participated in politi- cal debates. However, the only year he spoke at meetings of the Consulte - an advisory board to the Florentine government - was 1410, when he was also elected to the gonfaloniere, covering the period between January and April, the possible time of Manetti's story. ${ }^{51}$ Although members of the Mannini family worked for Pippo Scolari and settled for life in the Kingdom of Hungary, I have not succeeded in tracing any connection between them and the woodcarver. Similarly, no archival sources have come to light on the existence of a certain Matteo Mannini. ${ }^{52}$ There are no direct references at our disposal which would underline the acquaintanceship between Manetto and Brunelleschi either. Only the Scolari family links the woodcarver to the architect. The Scolari Oratory in Florence, founded by the testaments of Pippo Scolari's brother and cousin, was designed and built by Brunelleschi in the 1430s. It seems to me that the Scolari intended to use the oratory as a family chapel, and thus very probably had the upper hand in the choice of a master. La Novella also mentions two other woodcarvers, one who took Manetto to Hungary and worked in Pippo Scolari's service and Pellegrino delle Tarsie, who was their master during their apprenticeship in Via delle Terme. Even though I did not manage to identify any of them, because all the other protagonists of the story were real historical figures, 


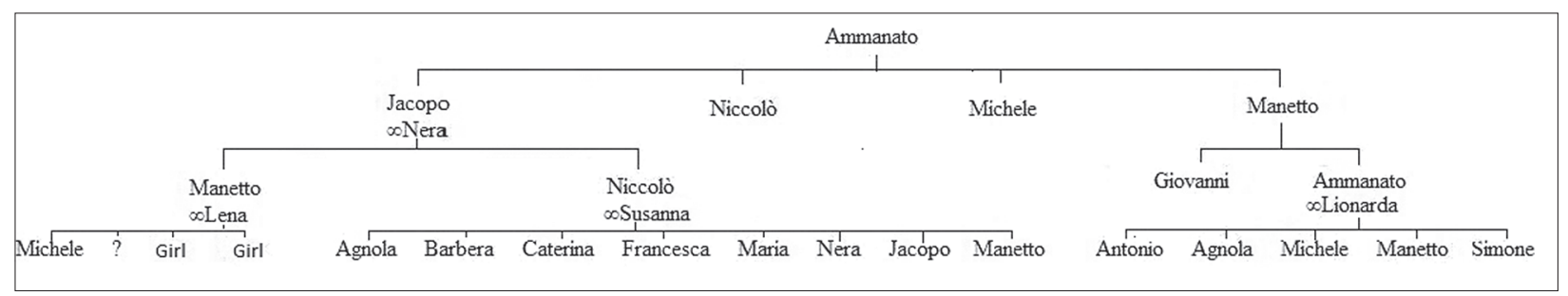

Fig. 3. The genealogy of the Amannatini family (The family tree is based on the tax declarations of the Amannatini family, as well as on the corresponding entries of the Prestanze, cited in the course of the text.)

we have no motivation to think their character was invented. ${ }^{53}$

Martines suggests in his essay that the style of interaction between the protagonists of La Novella as well as their names reflect their social status in Florence as well as a group hierarchy. He claims that "to have a family surname in early fifteenthcentury Florence was already to be someone." ${ }^{n 4}$ Based on these observations, Martines maintains that Manetto the woodcarver was socially inferior to the rest of the company. ${ }^{55}$ This seems to have been true in 1410 , in relation to the majority of the company except Donatello; however, by the late $1420 \mathrm{~s}$, the picture might have become quite different. All of the friends, Brunelleschi, Donatello and Manetto, were at the peak of their careers at the time of the first general censuses; Brunelleschi was leading the construction of the cupola of the Florentine cathedral (1420-1436), and Donatello was cooperating with Michelozzo on various projects. ${ }^{56}$ In 1427, Brunelleschi had 1233 Florins and the Amannatini 1567 Florins of taxable assets. Six years later, in 1433, the households headed by Brunelleschi and Manetto's mother paid the same amount of tax; in fact the Grasso's family had more taxable assets than Filippo did. ${ }^{57}$ Donatello, by contrast, did not possess any taxable assets in 1427 or $1433 .^{58}$ Both Filippo and Donatello had properties only in Florence; therefore they were probably less well off than the woodcarver. Manetto, besides his assets in Florence, definitely had other properties in the Kingdom of Hungary, which remain uncovered by Florentine sources. At the time of the catasti, he still enjoyed the support of his major patron, King Sigismund, from whom he received an annuity, and his other patron, Lo Spano, had died only a couple of months earlier, in December $1426 .{ }^{59}$

Further evidence regarding the Grasso's financial circumstances indeed underline that he acquired some financial stability and social sta- tus in Hungary. ${ }^{60}$ His savings reported in the tax returns and registered in the books of the Monte Commune suggest that his income might have far exceeded that of an average Florentine artisan of the period. In 1427, about 17 years after his arrival in the Kingdom of Hungary, he already had 1790 Florentine Florins of public loan. ${ }^{61}$ As years passed the sum only increased, in six years to 3300 Florins and by 1442 reaching 3821 Florins. ${ }^{62}$ He also had 270 (Florentine?) Florins of cash deposited in Hungary with a Venetian merchant. Furthermore, the Florentine Simone di Pagolo Carnesecchi and his brothers in Hungary were safekeeping 128 Hungarian Florins for him. The source also mentions that the sum was part of a business deal (ragione) the Grasso had in Hungary. It seems to me that Simone acted as a personal banker to the woodcarver, since he was also managing his Monte shares and paying taxes on his behalf. ${ }^{63}$

Besides his loans to the public debt, Manetto also invested in the dowry fund in his daughters' names. ${ }^{64}$ It is interesting, however, that in spite of a prosperous life, he did not considerably enrich the family patrimony in Florence. In 1427, the Amannatini owned only a relatively small parcel of land in Paterno, near Pontassieve. ${ }^{65}$ The old family house was probably sold for the sake of the construction of the cathedral; thus, they purchased a new home in Via de Macci, the parish of San Simone, Bue gonfalon, Santa Croce quarter. $^{66}$

All this information about Manetto's finances suggests that he managed to improve his social status considerably by migrating to the Kingdom of Hungary. The claims of Antonio Manetti, according to which the Grasso was employed as Pippo Scolari'architect, also seem to be underlined by this evidence, since no woodcarver even of the highest recognition could have acquired such prosperity in Florence as Manetto did. ${ }^{67}$ 
Besides Manetti's story, also the Commissioni of Rinaldo di Maso degli Albizzi, ambassador to King Sigismund, suggest that the woodcarver took an active part in construction works commissioned by Pippo Scolari. The Florentine politician - who then would have been a relative inlaw of the Spano - met the Grasso while visiting his residence located in the Transdanubian area. A small town of local interest called Ozora became the center of the baron's properties in Hungary. He put serious efforts into its improvement by founding a chapel and an observant Franciscan convent there, restoring the local parish church and erecting a castle, voluminous building projects which went on between the 1410s and 1420 s. Manetto was not simply visiting Ozora in 1426; instead he probably lived there permanently, and thus the ambassador called him "Manetto da Osora, bene che sia fiorentino." "68 His possible participation in the construction works in Ozora is also supported by the summary of a letter, found in the Florentine National Archives, according to which in June 1427, six months after the Spano's death, his heirs were still indebted to Manetto in the amount of 1000 Florins "per lo lavorio del castel(lo?) d'Osola." "69 Though the entry had consequently been cancelled and damaged it still proves that the castle in Ozora - unique in some aspects for Hungarian castles of the period - was likely erected with Manetto Amannatini's assistance. ${ }^{70}$

Besides the castle, Manetto's surviving testament, written in 1428, implies a connection between him and the observant Franciscans as well as their two newly erected convents in Ozora and in Florence. The document, issued in the parish of the San Miniato al Monte Church in Florence, proves that Manetto wished to be buried in the Franciscan convent of Santa Croce. By the document, he intended to leave 500 Florentine Florins of public debt for the construction of the observant Franciscan convent of the San Salvatore al Monte, supervised by the Calimala Guild, later main patron of the convent, located in the immediate vicinity of the San Miniato al Monte. ${ }^{71}$ The Calimala Guild, the observant Franciscans as well as the San Salvatore al Monte were closely related to the Scolari family. After Matteo's and Andrea's Scolari deaths, in 1426, it was the Calimala Guild to supervise their heredity, therefore the construction of the Scolari Oratory. The Sco- lari were important patrons of the observant Franciscans. Manetto, in his last will issued in 1422 , stated that he wished to be buried in the property of the observant Franciscans, located nearby the San Miniato al Monte. ${ }^{72}$ Already in 1418, there was a well-off Florentine, named Luca di Jacopo della Tosa to donate his nearby properties to the order. A year later, the observants started to erect their first church there of which constructions lasted until $1435 .^{73}$ In 1422 , Matteo Scolari's testament already mentions the convent of the order, though most probably there was only a chapel completed. Since Matteo Scolari died in Hungary, there are no other sources, which would allude to further connections between the Scolari and the San Salvatore al Monte. Members of the Della Tosa (Tosinghi) family, however, were engaged in trade in Hungary and belonged to Matteo Scolari's business network. ${ }^{74}$ That the Scolari were important supporters of the observant Franciscans shows also the fact that Pippo, in 1418, supplicated to the pope for constructing a convent in the center of his estates in Ozora, Hungary. ${ }^{75}$ In 1423, the convent was already completed and later grew into a regional center of the order. Since back then, Manetto was most probably living in Ozora, we shall hardly doubt that he had an active role in the construction of the convent as well. Interestingly, also one of the friar-witnesses of Manetto's testament was originated from Hungary, which shall also underline the connection between the foundations of the two convents, in Florence and in Ozora, in 1418. The Grasso's intention to leave 500 Florins to the Calimala Guild had a scope similar to that of Andrea and Matteo Scolari, who wished to found two monasteries on their estates. The sum of by no means insignificant size also shows that Manetto, indeed, acquired a considerable wealth in Hungary. ${ }^{76}$ If he had any other "professional" connection to the San Salvatore al Monte, by actively participating in its construction, we do not know, but his donation was designed to contribute to the foundation of the first observant convent in the city of Florence.

Following the Spano's death, Manetto definitely remained in the Kingdom of Hungary and very likely worked for King Sigismund himself. Social status in Renaissance Florence was not only about money but also about connections and reputation, both abundant in the Grasso's 
case. Thanks to his employment in the royal court, Manetto might have counted on the ruler's support in the 1430s. According to Rinaldo degli Albizzi, the Grasso even mediated from time to time between Sigismund and the Florentine Signoria. ${ }^{77}$ Even though the ambassador might exaggerate here, the woodcarver's connections to the royal court are without question. From Ozora, he might have moved to Buda, the seat of Sigismund. While there, his experiences were probably a far cry from the image depicted by Bergstein, who stated, "Compared with the forests of Central Europe, where the woodcarver Grasso ended up, Padua, with its university, its humanist culture, and its Florentine connections, must have looked like paradise."78 On the contrary, Donatello might have rightfully developed resentments toward the Grasso, who ended up at the court of the Holy Roman Emperor, accompanied by fellow-Florentines, humanists and other prestigious foreigners. ${ }^{79}$ In fact, we find him in Buda in 1444 acting as one of the witnesses of the humanist Pier Paolo Vergerio's last will. ${ }^{80}$

The hypothesis that Manetto the fat woodcarver was acquainted with the highest circles of humanists is supported by much indirect evidence, including La Novella itself, which clearly shows that respected citizens and artisans with some interest in humanist studies, such as Filippo Brunelleschi, accepted his friendship. Also, the Scolari were acquainted with important humanists, like Poggio Bracciolini and Ambrogio di Bencivenni Traversari, which might have given the Grasso the opportunity to develop contacts with them. In addition, the appellative of his brother might indicate that the Amannatini brothers knew several leading humanists of the time. Niccolò in the tax returns mentioned that he was called Lausso. ${ }^{81}$ This nickname is highly unusual, not only for an artisan of modest social status, but also for anyone who did not have familiarity with ancient authors. We could hardly associate this name with anyone other than Lauso, one of the protagonists of Virgil's Aeneid. Lauso appears in book $\mathrm{X}$ as a young adversary of Aenea. ${ }^{82}$ Though many Florentine artisans were literate, reading Virgil might not have been a widespread practice. Humanists were familiar with the story of Lauso - the good-hearted offspring of the Etruscan tyrant, Mezenzio -, who dies by the sword of the Troyan Aenea. In fact, a rima written around 1439 by an unknown author for the occasion of the construction of the organs for the Florentine cathedral recalls the figure of the buon Lauso. The work, besides Lauso, refers only to real persons, among them the chief architect of the cupola, Brunelleschi. ${ }^{83}$

Only Florentine sources are at our disposal when reconstructing Manetto's life in the Kingdom of Hungary. It seems to me that his settlement was definite, and he might not have spent years, but only short periods, in Florence after $1410 .{ }^{84}$ The only time when he was surely in the city after having received employment in Pippo Scolari's service, was in 1428, when he made his last will.

Thus, we learn that Manetto was still unmarried at the time of his arrival in Hungary and started a family only there. His wife, called Lena, seems to have a Florentine name, though Florentine sources in almost all cases transform foreign names. We have no further information on her family background and origins. They got married sometime between 1428 and 1432; in 1433 they already had a one-year-old son, Michele. ${ }^{85}$ The age difference between the two might have been considerable, as Lena - in a similar fashion to the majority of Florentine girls - was still a teen at the time of their marriage. ${ }^{86}$ By 1447 , the couple had four children: two daughters, one boy and another child, all of them still unmarried in $1452 .^{87}$

By King Sigismund's death in 1437, the financial circumstances of the family - according to Manetto's own words - had changed drastically. ${ }^{88}$ This might have been an exaggeration in the view of avoiding taxation, since his brother and his family likely lived still on Manetto's money. The woodcarver died sometime between 1450 and 1452, most probably in Hungary, and it seems to me that his widow and children never returned to Florence. ${ }^{89}$

The story of the Fat Woodcarver, written by Antonio di Tuccio Manetti, definitely has a solid basis in its protagonist Manetto di Jacopo Amannatini's life. He was indeed a woodcarver, living in the parish of San Giovanni, of modest but not humble origins, and he was probably acquainted with the architect Filippo di ser Brunellesco. Being unsatisfied with his financial and social circumstances, he went to the Kingdom of Hungary, where he worked in Pippo Scolari's service. While there, he acquired considerable wealth and a reputation as an artisan in charge of the 
construction of buildings. He was later patronized by King Sigismund himself, and settled in the Kingdom of Hungary for the rest of his life. Thus, Manetto became the earliest known artisan of Florentine origins who migrated beyond the Alps, in the view of obtaining the success and wealth offered by a royal or princely court. To what extent he mediated the emerging Florentine style in the Kingdom of Hungary, we do not know. Yet, his story provides us with a unique picture of the intersections that existed between merchant and artisan networks in early Renaissance Florence, hardly imaginable elsewhere in Europe at the time.

\section{APPENDIXES}

DOCUMENTS

\section{THE TAX RETURN OF MATTEO AMANNATINI'S MOTHER IN 1427 (ASF, CATASTO 31.)}

\section{fol. 846r}

Al nome di Dio amen

Dinanzi a voi signiori uficiali del chatasto della città di Firenze

Sustanze e beni di mona Nera donna fu di Jachopo Amannatini e figliuoli, gonfalone Bue à di prestanzone fi.1 s. 9.d.8 a oro.

Una chasa ove abito chon maserizie a mio uso posta nella Via de Macci dal Munistero di Sancto Francesco chonfini di detta chasa a primo via sechondo Antonio di Spigliato banderaio terzo la chonpagnia del tenpio, quarto Nuccio di Maso pelachane

Un podere posto nel popolo di Sancto Istefano a Paterno luogho detto Al Pogio a luogholo a Pezi in due persone.

Lavorane una parte Andrea chiamato El Cintore e un'altra parte Michele da Chasalino, chonfini di detto podere a primo via sechondo Tomaso di messer Tomaso Sacchetti terzo figliuoli erede di Chonte Peruzi quarto la chonpagnia di Sancta Maria del Bighiallo.

Rendite di detto podere

Grano istaia 24

Fave istaia 6

Vino barili 12

Olio orcia 6

Charne di porcho libra 50

Uno chappone

Di frutte trafichi sechi e nocie e pere e mele in tutto fi. 1
Danari in sul Monte di quegli sono del Monte chomune chon ritenimento del quarto fi. 1790 i quali denari sono ischriti in Manetto di Jachopo Amannatini figliuolo della sopradetta mona Nera nel quartiere di Sancta Croce. ${ }^{90}$

Agiunse dovere avere Manetto suo figliuolo da Simone di Pagolo Carnesechi e fratelli deono dare per la ragione d'Ungheria fi. 120 denari ungheri fi. $128 \mathrm{~s}$.

Francescho di Neli Ghuadringieride dare duchati dugiento cinquanta di viniziani e quali gli die Manetto in Ungheria che gli facessi buoni in Firenze a volontà del detto Manetto fi. $270 \mathrm{~s}$.

\section{fol. 846v}

al nome di Dio amen.

Incarichi di detta mona Nera ò a dare

A Pagholo di Merchanto detto Chastellano fi. lbr. $14 \mathrm{~s}$.

A Papi d'Ugholino choltriciaio fi. lbr. 6. s

A Michele da Chasalino mio lavoratore fi. lbr. 4.s.

Mona Nera è detta d'anni 65

Manetto suo filgiuolo deta d'anni 40

Il detto Manetto ista ' $n$ Ungheria

Nicholo suo filgiuolo deta d'anni 38

sanza ghuadagno uno

Io Pippo di Nicholo fu presente chome mona Nera rechò la sua scritta. 


\section{THE TAX RETURN OF MANETTO AMANNATINI'S MOTHER IN 1433 (ASF, CATASTO 447.)}

\section{fol 358r}

Al nome di Dio a dì xxx d'aghosto 1433

Sustanze e beni di mona Nera donna che fu di Jachopo Amanatini e di figliuoli

A Manetto suo figliuolo iscritti in sul Monte Chomune circha di fi. 3300

Di detti denari ne suto prochuratore Simione Charnesechi e àne ricieuto le paghe e paghato sue graveze detto Simone v'aviserà d'ogni chosa I podere posto nel popolo di Santo Istefano a Paterno luogho detto A Pogio da primo via ser Tomaso Sachetti 1/3 figliuoli di Chonte Peruzi 1/4 figliuoli di Giugliano di Pierozo ispeziale

Que'1 detto podere s'afitta a Antonio di Giovanni di Spigliato e debea dare per v anno fi. 16 l'anno di lbr. 4 il fi. Quello anchora a tenere 18 mesi il quale podere s'afitto per rachonciare le chase ch'erano ronvinate e il detto Antonio dicie avere paghato per detti v anni.

I chasa posta in Firenze nella quale ista Piero Chonpiubeli dame l'ano fi. 5, la quale chosa àne a sino vita que no' lla può ne vedere ne impegniare ${ }^{91}$
Incharichi di detta mona Nera

Ista a pigione inn una chasa che d'Antonio di Spigliato a paghare fi. 9 l'anno che a Ognisanti a me avere il detto Antonio fi. 9

Boche di detti sono v

Mona Nera detta d'anni 70

Manetto deta d'anni 48

Niccholo deta d'anni 44 non è in suo sentimento Mona Lena donna di detto Manetto deta d'anni 26

Michele di Manetto deta d'anni 1

Abiamo a paghare in chomune fi... e detti denari ci chonviene paghare che $\mathrm{v}$ delle vendite vogliono vendere i nostri beni.

Que ppiù potrebbe esere perchè Manetto mio figliuolo è nelle paesi d'Ungheria che gli àrebe degli incarichi e del mobile che a me no' sono noti e più mesi fa gli feci iscrivere che mene avisasi e per anchora risposta non ò auta chome l'arò vene farò avisati.

\section{THE TAX RETURN OF MANETTO AND NICCOLÒ AMANNATINI, IN 1446 (ASF CATASTO 661.)}

\section{fol $753 r$}

Santa Croce gonfalone Bue

Manetto e Niccholo di Jachopo Amanatini ànno di graveze in detto gonfalone

Nella decina fi. 2 s. 6

Nel dispiacentte fi. 2 s. 6

Nel primo catasto fi. 5 s. 5

\section{Sustanze}

Una casa per nostro abitare posto nel popolo di San Simone gonfalone detto a primo via secondo l'abate de Fagni a iii dato d'Antonio da Feghine Un poderetto posto nel popolo di Santo Stefano a Paterno a primo via secondo Tomaso Sacchetti e a iii Bernardo Mellini e

E quale pode afittato Andrea d'Alderigho orafo Del gonfalone Nicchio per pregio di fi. 14 l'anno
Denari di Montte

Fi. 3821 di Montte Chomune iscritti in Manetto e parte in mona Nera nostra madre che sono circha a fi. 350 o circha iscritti in detti. ${ }^{92}$

Bocche

Manetto d'anni 62

Mona Lena sua dona d'anni 30

4 figliuoli di detto Manetto non sappiamo i nomi perché sono in Ungheria

Niccholo sopradetto d'anni 56

Mona Susanna sua dona d'ani 26

Angiola sua figliuola d'ani 10 non à dote

Maria sua figliuola d'anni 8 non à dote

Barbera sua figliuola d'anni 6 non à dote

Nera sua figliuola d'anni 4 non à dote

Jachopo suo figliuolo d'anni 2

Francescha sua figliuola mesi 1 


\section{THE TAX RETURN OF MANETTO'S BROTHER, NICCOLÒ AMANNATINI, IN 1451 (ASF CATASTO 697.)}

\section{fol 689r}

Al nome di Dio a dì di xv d'aghosto 1451

Quartiere Sancta Croce gonfalone Bue

Nicholo di Jacopo Amannatini vocato Lausso

Ebbe di gravezze nella $\mathrm{x}$ (decina) del 47 fi. 2.12 .8

Fui sgranato soldi 6 resto in fi 2.6.8.

E graziato in fi fi.1.10.

Detta gravezza dicie in Manetto e Nicolo di Jacopo Amannatini

Mia perché detto Manetto è morto la fò dire infine Sustanze

Una chasa posta nella Via di San Francescho e nel popolo di San Simone che di primo via secondo
Antonio di Spigliato 1/3 1/4 spedale del temppio, la detta chasa abito chon lla mia famiglia

Un podere posto nel popolo di Santo Istefano a Paterno chon ppiù pezzi di terra sodi e boschi cho' loro veri confini, sono usato d'affitaello in fi. 14 l'anno già ffa più tenppo ora lo tengho io rende in parte

Grano staia 20

Vino barili 8

Olio orcia 6

I detti beni si dettono nel primo catasto in nome di mona Nera donna fu di Jacopo Amannatini e figliuoli in detto gonfalone Bue.

\section{THE TESTAMENT OF MANETTO AMANNATINI, IN 1428 (ASF, NOTARILE ANTECOSIMIANO 18510, NOTARY: ANTONIO DI SER JACOBO DI BONACCORSO SALVETTI DA PISTOIA) ${ }^{93}$}

\section{fol 424v}

1428, mccccxxviii, indictione vi

Item eisdem anno et indictione die verovigesimoquarta mensis maii. Actum in populo Sanctis Miniatis ad Montem prope Florentiam in conventu infrascripto presentibus testibus ad hoc habitis et ore proprio infrascripti testatoris vocatis et rogatis fratribus Nicolao Benozi, Masseo Lapini, Antonio Ugolini, Johanne Luce omnibus de Florentia, Nicolao Johannis de Tripoli de Soria, Michaele Bartoli de Florentia, Benedicto Martini de Ungaria, Petro Laurentii de Gambasso, omnibus fratribus ordinis Beati Francisci de observantia vulgariter nuncupatiset aliter.

Cum nihil morte certius die vero et hora incertius idcirco prudens et discretus vir Manettus olim Jacobi Amannatini legnaiuolus populi Sancti Simonis de Florentia habitator olim in partibus Hungarie, sanus Dei gratia mente corpore et intellectu divinum timens iudicium et intestatus decedere nolens quod de se suis quod bonis post eius mortem fieri velit per praesens suum nuncupativum testamentum quod dicitur sine scriptis in hunc modum disponitur et facere procuravit videlicet.

In primis quidem animam suam omnipotenti Deo et gloriose Beate Marie semper verginis ac Beato Francisco toti que celesti curie recommendans sui corporis sepulturam cum exhac vita migraverit elegit conventum Sancte Crucis si eum Florentie mori continget et si alibi apud conventum Sancti Francisci eiusdem loci.

Item reliquit et legavit operi nove sacrestie Sancte Reparate et operi et constructioni murorum civitatis Florentie libram quattuor <illegible word> ambo dicta loca.

In omnibus autem aliis suis bonis mobilibus et immobilibus iuribus nominibus creditis et actionibus suos universales heredes instituit fecit et esse voluit omnes et singulos filios domini testatoris legitimos et naturales unum et seu plures nascituros ex se et qualibus exuxore legiptimam etiam postumum ut postumos.

Item reliquit dominam Neram ea matrem et uxori olim domini Jacobi Amannatini usufructuariam omnium suorum bonorum donec vixerit una cum dictis fillis domini testatoris.

Tutores vero et pro tempore curatores dictorum filiorum domini testatori reliquit fecit et esse voluit offitiales pupillorum civitatis Florentie.

Et in quantum contingat dictum testatorem decedere absque filiis legiptimis et naturalibus aut quod eius filii legitimi et naturales nascituri ex se et qualibus exuxore legitimam etiam postumi decederent quandocumque sine filiis legitimis et naturalibus tunc et in dictis casibus et quolibus eorum reliquit et legavit amore Dei et pro remedio anime sue florenos quinquagentos et seu cre- 
ditum florenorum quinquagentorum scriptorum in dictum testatorem cum maiorem summam super monte communiset libris montis communis Florentie consulibus Artis Callimale et mercatoribus civitate Florentie pro tempore existentibus. Ad hoc ut ipsum creditum vendatur et seu permutetur in quoscumque volverint et primum inde retrahendi convertant in

\section{fol 425r}

Indictione vi

mecccxxviii indictione vi

subsidium dotium pauperum puellarum que nupserint et nondum matrimonium consumaverint ita tamen quod non possint erogare alicui ex dictis puellabus ulteri florenos decem pro qualibus earum aggravans in his exequendis conscientias dictorum consulum quos ad hoc omnia speciales executores reliquit. Et insuper fecit constituit et ordinavit suos veros et legitimos procuratores, actores, factores et certos nuntios speciales duraturi post mortem dictos consules Artis Callimale presentes et futuros specialiter et nominatim ad vendendi permutandi et transferendi in quamcumque personam locum commune collegium et seu unversitatem cum quacumque conditione separatim coniunctim divisim semel et plures dictum creditum florenos quinquagentos montis communis videlicet usque in florenos quinquagentos montis communis descriptis in dictum testatorem cum pagis donis et interesse tam ordinis quamextraordinis et tam debitis quam debendis et aratione et computo domini testatoris removeri et levari faciendi et in alios quoscumque transferendi prout et sicut et quem ad modum dictis suis procuratoris videbituret placebit et dandum licentiam scribendis montium communis Florentie predicta faciendi nec non ad faciendum finem quietam remissionem et pactum de ulterius non petendo a dicto communi Florentie vel eorum casum vel scribendis occasione dicti crediti. Et generaliter ad omnia et singula facienda procurandi et exercendi in predictis et quolibet predicta necessaria utilia vel quodlibet oportuna et que ipsem et constituens facere posset si adesset dans et concedens dictus suis procuratori in predictis et circa predicta et quolibet eorum plenum liberum et generale ac speciale mandatum cum plena libera et generali administratione nec non promittens et conveniens in Antonius notarius infrascripti ut et tamquam publice persone stipulanti et recipienti vice et nomine dictum consulum et omnium quorum interesse posset se perpetuo firmum et ratum habiturum omne id totum et quicquid per dictos suos procuratores actum gestum et procuratum fuit et contra non facere vel venire sub pena et obligationum sive suorumque heredum et bonum omnium presentes et futuri.

Item in dictis casibus et quolibet dictorum casium reliquit et legavit amore Dei fratribus capitulo et conventui Sancti Francisci de Sancto Miniate ad Montem propre Florentia de obserantia vulgariter nuncupatis florenos quinquagentos et seu creditum florenos quinquagentorum montis communis scriptis cum maiori summa in dictum testamentum super libris montium communis Florentie quod creditum vendi iussit et voluit perinfrascriptos consulis Artis Callimale presentes et futuros et quod primum inde retrahendi convertant et expendant in fabricam et constructionem et seu necessitatibus diciti conventis pro remedio anime dicti testatoris et ut dicti fratresorent pro eo. Ad que exequenda dictos consules speciales executori fuit reliquit et esse voluit. Et insuper fecit constituit et ordinavit suos veroset legitimos procuratoris actores factores et certos nuntius specialis duraturi post mortem dictos consules Artis Calimale presentes et futuros spetialiter et nominatim ad vendendi permutandi et cetera dictum creditum florenos quinquagentorum. In omnibus et peromnia ut superius in precedenti legato continetur.

\section{fol $425 v$}

Item in dictis casibus et quolibet eorum reliquit et lagavit domine Nere eius matriet uxori olim dicti Jacobi Amannatini toto tempore eius vite usumfructum reddita et proventuspagas dona et interesse florenorum mille et seu crediti florenorum mille montis communis scriptiin dictum testatorem cum maiori summa super libris montis communis Florentie. Constituens ipsam dominam Neram eius procuratricem duraturam post mortem domini testatoris ad predictas pagas dona et interesse tam ordinaria quam extraordinaria exigendi et recipiendi et se habuisse et recepisse confitendi semel et plures et totiens quotiens volverint. Idem ad finienda et ceterapost mortem vero ipsi domine Nere reliquit et legavit libere dictum creditum fratribus capitulo et conventui Sancti Francesci de Sancto Miniato ad Montem de observantia vulgariter muncupatis convertendi et expendendi in fabricam et constructionem dicti conventis et necessitatibus eiu- 
sdem per consules Artis Callimale predictes quos ad predicta speciales executori reliquit. Et insuper constituit dictis consulis suos procuratoris duraturi post mortem et cetera ad permutandi et alia omnia ut superius continetur in alio legato. Item in dictis casibus et quolibet eorum reliquit et legavit Nicolao fratri germano ipsius testatoris et filio olim domini Jacobi Amannatini et eius filiis legitimis et naturalibus florenos quinquagenta et seu creditum florenorum quinquagenta montis communis scriptorum in dictum testastatorem maiorem summa super libris montis dicticommunis Florentie.

Cum hac conditione quod dominus Nicholaus non possit vendere alienare permutare vel aliquo titulo alium transferre dictum cerditum in totum vel in partem. Et in quantum dictus Nicolaus decesserit sine filiis legitimis et naturalibus aut eius filii legitimi et naturalibus decesserit ante statem legitimam voluit dictum creditum florenorum quinquagentorum pervenire et in dictorum casium et casibus ipsum legavit fratribus capitulo et conventui Sancti Francisci de Sancto Miniato ad Montis predictis convertendi et expendendi in fabricam et constructioni et necessitatibus dicti conventis per consules Artis Callimale predictos quos ad predicta speciales executori reliquit. Et insuper constituit dictis consulis suos procuratoris duraturi post mortem ad permutandi dictum creditum et cetera ut superius.
Item in dictis casibus et quolibet eorum reliquit et legavit Juliano Michaelis Amannatini eius fratris consobrino de Florentia et eius filiis legitimis et naturalibus florenos quinquagentos et seu creditum florenorum quinquegentos montis communis scriptorum in dictum testatoremcum maiorem summam super libris montis communis Florentie. Cum hac conditione predictus Julianus non possit dictum creditum in totum vel in partem vendere alienare permutare vel aliquo titulo in alium transferre. Et in quantum dominus Julianus decesserit sine filiis legitimis et naturalibus aut eius filii legitimi et naturales decesserit ante statem legitimam voluit dictum creditum florenorum quinquagentorum pervenire et in dictorum

\section{fol 426 r}

Indictione vi

casium et casibus ipsum legavit fratribus capitulo et conventui Sancti Francisci de Sancto Miniato ad Montem predicti convertendi et expendendi in fabricam et constructioni dicti conventis et necessitate sitis per consules Artis Callimale predictos quos ad predicta facienda speciales executor reliquit. Et insuper constituit dictis consulis suos procuratoris duraturi post mortem et ad permutandi dictum creditum et ut superius cum clausulis opportunis. Et hanc asseruit velle esse suam ultimam voluntatem in quam valere voluit et cassans et cetera.

\section{NOTES}

\footnotetext{
${ }^{1}$ Lauro Martines: An Italian Renaissance Sextet: Six Tales in Historical Context, Toronto, 2004. 221.

${ }^{2}$ Ruggiero maintains that Manetti and Filippo di ser Brunellesco knew each other. Guido Rugciero: "Mean Streets, Familiar Streets or The Fat Woodcarver and the masculine spaces of Renaissance Florence," in Renaissance Florence: A Social History, eds. Roger J CuM, John T PAOLETTI. New York, 2006. 295-310, 297-298.

3 Mary Bergstein: "The Fat Stonecarver," in Orsanmichele and the History and Preservation of the Civic Monument, ed. Carl Brandon STREHLKE. Washington, 2012. 187-196, 191.

${ }^{4}$ Giuliano TanturLi: "Introduzione," in Vita di Filippo Brunelleschi, preceduta da La novella del Grasso, ed. Domenico DE RoBERTIS with the introduction of Giuliano Tanturli. Milano, 1976. XX.

${ }^{5}$ Gaetano MiLANESI: Operette istoriche edite ed inedite di Antonio Manetti matematico ed architetto fiorentino del secolo XV, Firenze, 1887. XI; André RocHON: Formes et significations de la «beffa» dans la littérature italienne de la Renaissance, Paris, 1975. 239-240; TANTURLI: "Introduzione," XXIII

${ }^{6}$ Margaret HaInes: "Brunelleschi and Bureaucracy: The Tradition of Public Patronage at the Florentine Cathderal," I Tatti Studies in the Italian Renaissance 3. 1989. 89-125, 108-110
}

${ }^{7}$ Francis William KENT: "A Letter of 1476 from Antonio di Tuccio Manetti mentioning Brunelleschi," The Burlington Magazine 121. 1979. 648-652.

${ }^{8}$ So far my attempt to connect the humanist's family to Filippo di ser Brunellesco, to Manetto Amannatini or to any of the protagonists of the story has been unsuccessful. See the tax return of Antonio's father, Tuccio di Marabottino Manetti in 1433. ASF Catasto 443. 592r-593v his campioni in 1427: ASF Catasto 67. 111r-113v. His original declaration in 1442 ASF Catasto 613.580r-581v.

${ }^{9}$ Domenico Maria ManNi: Novella antica del Grasso legnaiuolo scritta in pura toscana favella ed ora ritrovata vera storia, Florence, 1744. 2-3; HAINES: "Brunelleschi and Bureaucracy," 108.

${ }^{10}$ The opening part of the declaration is missing from the transcription. MILANESI: Operette istoriche, XXV. For the original document see: ASF Catasto 615. 778r-780v.

11 Milanesi knew a good number of sources, among them tax declarations and guild matriculations; he did not refer, though, to their locations. MILANESI: Operette istoriche, XII-XXV.

${ }^{12}$ Antonio ManetTI: "La novella del Grasso," in Vita di Filippo Brunelleschi, preceduta da La novella del Grasso, ed. Domenico DE RoBERTIS with the introduction of Giuliano Tanturli. Milano, 1976. 3. An earlier version of the Novella 
says 1410. TANTURLI: "Introduzione," XXII. For a complete English translation of the story see: MARTINES, An Italian Renaissance Sextet, 171-212. In 1412, Filippo sued Donatello at the Merchant Court for business debt. Lorenz BöNINGER: "Brunelleschi, Donatello e la Mercanzia," Archivio Storico Italiano 174. 2016. 317-326.

${ }^{13}$ There are only sporadic references to Florentine goldsmiths who worked outside the Italian Peninsula. See Katalin PRAJDA: "Goldsmiths, Goldbeaters and Other Gold Workers in Early Renaissance Florence 1378-1433," Vierteljahrschrift für Sozialund Wirtschaftsgeschichte, ed. Eva JULLIEN (forthcoming).

${ }^{14}$ Martines: An Italian Renaissance Sextet, 172; MANetTI: "La novella del Grasso," 3.

${ }^{15}$ Richard A. GOLDTHWAITE: The Building of Renaissance Florence: An Economic and Social History, Baltimore, 1980. 358-359.

${ }^{16}$ Filippo Brunelleschi, l'uomo e l'artista:Ricerche brunelleschiane: Mostra documentaria: Catalogo, ed. Paola BENIGNI. Florence, 1977. 48.

${ }^{17}$ GOLDTHW AITE: The Building of Renaissance Florence, 29.

${ }^{18}$ Maria Letizia Grossi: "Le botteghe fiorentine nel catasto del 1427," Ricerche Storiche 30. 2000. 4-56, 8. Besides the legnaiuoli there were of course other woodworkers living in the city.

${ }^{19}$ Partners very often did not mention their existing company in the tax return; only the workshop was listed as part of the owner's immobile properties. ASF Catasto vols. 487-500, 455.

${ }^{20}$ Nardo di Andrea Becchi. Jacopo di Andrea Gianni. Bartolomeo di Tommaso Finiguerra, Bartolo di Giovanni Bindi, Filippo di Giovanni di Piero Canacci, Lorenzo di Niccolò del Corona and Manno Benincasa Manucci. Ibid.

${ }^{21}$ ASF Prestanze 366-369. It is important to note that the tax officials of the Prestanze seemingly more frequently recorded the occupation of the taxpayers than the citizens themselves did fifty years later in the Catasto.

${ }^{22}$ There are only two books covering Manetto's time among the records of the Arte di Legnaiuoli, the statutes ASF Arte dei Legnaiuoli 4, and a register with missing membership payments starting from 1421: ASF Arte di Legnaiuoli 6. Matriculations: ASF Arte di Pietra e Legname 1, 2.

${ }^{23}$ Katalin PRAJDA: "Florentine Merchant Companies Established in Buda at the Beginning of the 15th Century," Mélanges de l'Ecole francaise de Rome. Moyen-Age 125-1. 2013. Posted online: 21 October 2013, accessed: 4 June 2016. URL: http://mefrm.revues.org/1062

${ }^{24}$ ASF Signori, Missive, Cancelleria I, 26. 108v.

25 As the Novella narrates: "This Spano took under his wing all Florentines who went there and had any intellectual or manual skill..." MARTINES: An Italian Renaissance Sextet, 208.

${ }^{26}$ Anthony MoLHO: "The Brancacci Chapel: Studies in Its Iconography and History," Journal of the Warburg and Courtauld Institutes 60. 1977. 50-98.

${ }_{27}$ MANETTI: "La novella del Grasso," 39-41.

${ }^{28}$ For Pippo Scolari's history see: Katalin PRAJDA: "The Florentine Scolari Family at the Court of Sigismund of Luxemburg in Buda," Journal of Early Modern History 14. 2010. $513-533$.

29 "Now this young man had come to Florence at that time to see if he could recruit any masters of his craft and take them back to Hungary." MartinEs: An Italian Renaissance Sextet, 208.

${ }^{30}$ Domenico de Robertis and Giuliano Tanturli have also mentioned that the second version of the Novella, written around 1470-78, mentions that date. TANTURLI: "Introduzione," XXII

31 MANETTI: "La novella del Grasso," 4.

32 The 1447 catasto declaration, written by his brother, mentions that the Grasso might have been born sometime in 1385. ASF Catasto 661. 753r. In fact, the tax return submitted in his mother's name in 1427, informs us that Manetto at that time was 40 years old. ASF Catasto 31. 846v. Six years later, in 1433 , his mother lists him as of 48 years old. ASF Catasto 447. 358r.

${ }^{33}$ Martines: An Italian Renaissance Sextet, 216.

${ }^{34}$ In the 1378 Prestanze there are seven Florentines called Grasso, among them a votapozzi and a magister. ASF Pre- stanze 366-369. In the 1433 Catasto there are two persons with this appellative. ASF Catasto 487-500, 455. In the 1458 Catasto we find only one: ASF, Catasto Sommario dei campioni del Catasto del 1457. Nicola di Benozzo, called Grasso, is mentioned several times in 1425 as speaker at the Consulte. ASF Consulte e Pratiche 43. 22v, 35v, 60v, 67v, 69r, 84v.

35 The sons of Amannato Tecchini of Florence were sometimes mentioned as Amannatini, referring in this way to the name of their father. MANNI: Novella antica del Grasso legnaiuolo, 3.

${ }^{36}$ MILANESI: "Operette istoriche," XXII-XXIII.

37 Jacopo was the head of the family in 1378. ASF Prestanze 369. 64v. For his brothers see: ASF Monte Comune, serie II. 1805. $16 \mathrm{v}$

${ }^{38}$ MANETTI: "La novella del Grasso," 3.

${ }^{39}$ Milanesi did not mention the location of the sources. MILANESI: Operette istoriche, XXXIII, XXII. Michele di Amannato: ASF Medici e speziali 7. 113r. Giovanni di Manetto ASF Medici e speziali 7. 83r. Manetto d'Amannato ASF Medici e speziali 7 . $117 \mathrm{v}$.

${ }^{40}$ ASF, Prestanze 369. 64v

${ }^{41}$ The Amannatini as merchants: ASF Arte della Lana 25. 2r, Catasto 61. 963r. The Amannatini as rope makers: ASF Catasto $482.597 \mathrm{r}-599 \mathrm{v}$.

${ }^{42}$ Manetto in 1374 was consul of the merchant court. ASF, Mercanzia 193, Niccolò was gonfaloniere. ASF Consulte 16. 86r. Martines: An Italian Renaissance Sextet, 219.

${ }^{43}$ MARTINES: An Italian Renaissance Sextet, 215-219.

${ }^{44}$ In 1405 , the household was already composed by the three of them. ASF, Monte Comune serie III. 1805. fol. 16v.

${ }^{45} \mathrm{ASF}$, Catasto 31. 846v.

${ }^{46}$ ASF, Catasto 447. 358r.

47 ASF Catasto 615. 779r, published in MILANESI: "Operette istoriche," XXIX.

${ }^{48}$ See the portate of Giovanni Amannatini: ASF Catasto 482. 598r and the campioni: Catasto 61. 963r.

${ }^{49}$ See the catasti published below and his declaration in 1458: ASF Catasto 801. 865r.

${ }^{50}$ In 1427, Giovanni di Bernardo submitted his tax declaration with his cousin, whose father, Donato Rucellai was a goldsmith. They also included into the document a debt, the painter Masolino was supposed to pay to Donato. ASF Catasto 46. 869v.

${ }^{51}$ ASF Consulte 40. 116r, 126r, 130r, 132r, 135r. He had already died by the time of the first general census in Florence, and his sons' declaration shows no connection to any members of the company. For the declaration of his sons in 1433 see: ASF $474.627 \mathrm{r}-631 \mathrm{v}$. I have not checked their declaration in 1427.

${ }_{52}$ No members of the Mannini family submitted a tax declaration in 1433. In 1427 there is only one Mannini household, Antonio Mannini and his sons, none of them called Matteo. ASF Catasto 72. 259r. This household of the family was located in the Santa Croce quarter and not in the Oltrarno as La Novella says. For the history of the Mannini in Hungary see: Katalin PRAJDA: "Unions of Interest. Florentine Marriage Ties and Business Networks in the Kingdom of Hungary during the Reign of Sigismund of Luxemburg," in Marriage in Premodern Europe: Italy and Beyond, ed. Jacqueline MuRRAY. Toronto, 2012. 147-166. 53 "This is why Grasso determined to go away to Hungary, for he recalled that he had been asked to go, and decided to find the man who had invited him, a former associate of his who had studied with him under Master Pellegrino delle Tarsie, whose workshop was in the Via delle Terme. This young man had left Florence several years before and gone to Hungary, where he had done very well with the help of Filippo Scolari, known as Pippo Spano..." Martines: An Italian Renaissance Sextet, 207. Martines suggests in his article that the name "Pellegrino," or "wanderer," might bear symbolical meaning in the story. MARTINES: An Italian Renaissance Sextet, 236. However, there is no woodcarver named Pellegrino either in the 1427 or in the 1433 catasti or in the Prestanze 1378. There is, however, a certain Pellegrino Salvini, barrel maker (bottaio) registered in the Oltrarno, in the other side of the city. ASF Prestanze 366. 100r.

${ }^{54}$ Martines: An Italian Renaissance Sextet, 216. 
${ }^{55}$ Lauro MARTINES: Strong Words: Writing and Social Strain in the Italian Renaissance, Baltimore, 2001. 172-173; MARTINES: An Italian Renaissance Sextet, 217, 219.

${ }^{56}$ Margaret HaINES: "Myth and Management in the Construction of Brunelleschi's Cupola," I Tatti Studies in the Italian Renaissance 14/15. 2011-2012. 47-101, 4 7.

${ }^{57}$ For Brunelleschi's tax return see: ASF Catasto 474. 645r-v.

${ }^{58}$ For the campioni of Donatello's tax return in 1427 see: ASF Catasto 65. 319v, in 1433: ASF Catasto 498. 195r.

59 "...la mortte del Re, che chome fatto morto, e perdè la providigione..." ASF Catasto 615. 780r. Published in MILANESI: "Operette istoriche," XXVII.

The Story of the Fat Woodcarver also mentions that Pippo Scolari was generous to him: "When Grasso and his friend arrived in Hungary, they set to work and met with good fortune, for in a few years they became rich, relative to their condition and standing .... And Spano took him into the field with him on maneuvers and paid him well, and every so often, as was fitting for the occasion, gave him fine and lavish presents." MaRTINES: An Italian Renaissance Sextet, 210.

${ }^{61} \mathrm{ASF}$, Catasto 31. 846r

${ }^{62}$ ASF, Catasto 447. 358r. Catasto 615. 779v

${ }^{63}$ Simone Carnesecchi and his brothers at that time were running their own company in Buda, and they established long standing economic connections with the Scolari family, providing them with financial services. There is, however, no reference to Manetto in the declaration of the Carnesecchis' company. Katalin PraJda, "Florentine Merchant Companies Established in Buda."

${ }^{64}$ ASF, Monte Comune, serie II. 543. 161r. Milanesi mentions the Monte deposits without referring to the archival units. MILANESI: "Operette istoriche," XXV

${ }^{65} \mathrm{La}$ Novella mentions a certain Polverosa, which might be invented. MANETTI, "La novella del Grasso," 7.

${ }^{66}$ See their declaration in 1427.

${ }^{67}$ MANETTI: "La novella del Grasso," 42. For the average wage for skilled workers see: Goldthwaite: The Building of Renaissance Florence, Appendices.

${ }^{68}$ Commissioni di Rinaldo degli Albizzi per il Comune di Firenze dal 1399 al 1433, III. ed. Cesare Guasti. Florence. 1867-69.590.

69 "Più capitoli di una lettera da Buda a dì 28 di giugno 1427 (cancelled) De fiorini 1000 si pagharono per messer lo Spano a Manetto di Jacopo da Firenze per lo lavoro del Castel d'Osola." ASF Corporazioni Religiose Soppressi 78. 326. 370r.

${ }^{70}$ For the connection between Manetto and Ozora see: Katalin Prajda: "Manetto di Jacopo Ammanatini, the Florentine Woodcarver-architect and Pippo Scolari's Castle in Ozora," in Art and Architecture around 1400: Global and Regional Perspectives, eds. Marjeta CIGLENEČKI and Polona VIDMAR. Maribor, 2012. 75-79.

${ }^{71}$ In fact, we find his name among the creditors of the Monte Comune in 1428. There are three payments recorded under the same account. First 34 Florin, 3 lire and 4 soldi, 2 denari (paghe 3 fi 2790, fol.87). The second (paghe 3 ) 3005 Florins for Simon Pauli (Carnesecchi?) July 14, 142837 Florins, 2 lire, 1 soldi and 3 denari for Uberti Martini. The third on January 3, 142937 Florins, 2 lire, 1 soldi and 3 denari. ASF Monte Comune, serie II. 366. 102v.

72 "prope montis Sancti Miniatis de prope Florentinis" ASF Corporazioni Religiose Soppresse dal Governo Francese 78.326. 267r. For the connections of the Scolari to various religious orders see: Tamás Fedeles - Katalin Prajda: "Olyan vallásosan, szokásaiban és életmódjában olyan mértéktartóan élt. Adalékok Filippo Scolari és családja vallásosságához," Történelmi Szemle 57. 2014. 357-382.

${ }^{73}$ Linda Pellecchia NAJEMY: "The First Observant Church of San Salvatore al Monte in Florence," Mitteilungen der Kunsthistorisches Instituten in Florenz 22. 1979. 273-296. The act of donation of Luca della Tosa, cited by Pellecchia Najemy shows no connection to either Manetto or to the Scolari. ASF Notarile Antecosimiano 19337. 45r-v.
${ }^{74}$ PRAJDA: "Florentine Merchant Companies."

${ }^{75}$ He was also present at the council of Constance, in 1415 when the Franciscan observants obtained autonomy.

${ }^{76}$ For comparison, in 1435, Tommaso di Francesco Busini had donated the annual interest of his Monte commune shares of 1000 Florins for ten years to the Franciscans in order to construct a family chapel. Pellecchia Najemy: "The First Observant Church of San Salvatore al Monte," 288.

7 Guasti: "Commissioni," III. 536; Milanesi: "Operette istoriche," XXIV

78 Bergstein: "The Fat Stonecarver," 192.

79 Filippo di ser Brunellesco savs the following to the Grasso in the Novella: "You've really gotten rich out of it, and become acquainted with the emperor of the world and with Pippo Spano and with many other great princes and barons." MARTINES: An Italian Renaissance Sextet, 211.

${ }^{80}$ Baccio ZiliotTo: "Nuove testimonianze per la vita di Pier Paolo Vergerio Il Vecchio," Archeografo Triestino 2. 1906 249-261, 67.

${ }^{81}$ ASF Catasto 615. 778y

${ }^{82}$ Paola Gagliard: "Pallante, Lauso e l'ira di Enea," Aufidus 49. 2003. 21-59.

83 'L'orribile e famoso tuo strumento

O Mi glori no assai ci sare' grato

Sede' non fosse che Matteo da Prato

Dice eh' e* menatori faranno stento.

Ma s'el tuo Brunellescho uno arghomento

Trovassi da ssonarllo sanza fiato

Michele del Biancholino darà comiato

A molti avea (al: à già) staggitia dargli vento.

Ma ' 1 buon Lausso per levar resia

A porllo pensa in sulla alta tribuna

A ghuisa (al: in formai di lanterna a fantasia).

Ordina poi che quatro venti ad una

Dentro vi dieno cholla lor melodia

Sì dolciemente ch'el sole ella luna

Elle stelle ciaschuna

Venghan danzando a far rosto bollito:

Parrà del cielo il tuo stormento uscito." Giovanni POGGI: $I l d u$ omo di Firenze: Documenti sulla decorazione della chiesa e del campanile tratti dall'Archivio dell'Opera, Berlin, 1909. 113.

${ }^{84}$ We read in the Novella that "...over the span of several years, he returned to Florence for a few months at a time on a number of occasions." MaRTINEs: An Italian Renaissance Sextet, 211.

${ }^{85}$ ASF, Catasto 447. 358r. His wife was not yet mentioned in his testament written in 1428 .

${ }^{86}$ According to the 1427 catasto submitted by Manetto's mother, Lena would have been 26 years old, which might be an exaggeration, since later, in 1447, she was listed as 30 years old. Since a Florentine woman in her twenties would have been far beyond the average marriage age, she was most probably still a teen at the time of the first catasto.

For the girls see the dowry fund: ASF, Monte Comune, serie II. 544.115r. Monte Comune, serie II. 543. 154v. For their other children see the tax returns.

${ }_{88}^{8}$ ASF Catasto 615. 780r.

${ }^{89}$ Milanesi retains, on the basis of the Monte entries and Niccolò's catasto, that Manetto died in 1450. MiLANesI: "Operette istoriche," XXXI. It seems to me that he was still alive in 1450, when one of the Monte books, opened in that year, mentions his investments. ASF Monte Comune, serie II. 544 123v. (creditors' book, 1450-1451).

${ }^{90}$ ASF Monte Comune, serie II. 665. 102v

${ }^{91}$ See the tax return of Giovanni di ser Piero Conpibesi: "Nichollo di Jachopo Amanattini de avere della pigione dove noi istiamo fiorini cinque ne paghiamo l'anno fi. 5." ASF Catasto 453. 416v.

${ }^{92}$ ASF Monte Comune, serie II. 534. 139r. Denari del Monte vecchio (1441).

${ }^{93}$ I am indebted to Lorenz Böninger for drawing my attention to the document. 